\title{
SPINOPELVIC VARIABILITY ACCORDING TO THE ROUSSOULY CLASSIFICATON CURVE TYPE
}

\author{
VARIABILIDADE ESPINOPÉLVICA DE ACORDO COM O TIPO DE CURVA DA CLASSIFICAÇÃO \\ DE ROUSSOULY
}

\section{VARIABILIDAD ESPINOPÉLVICA DE ACUERDO CON EL TIPO DE CURVA DE LA CLASIFICACIÓN DE ROUSSOULY}

\author{
Raphael de Rezende Pratali, ${ }^{1}$ luiz Eduardo Moreira Passos, ${ }^{1}$ Carlos Eduardo Algaves Soares de Oliveira, ${ }^{1}$ Carlos Fernando P. S. Herrero ${ }^{2}$ \\ 1. Hospital do Servidor Público Estadual de São Paulo, Orthopedics and Traumatology Service, São Paulo, SP, Brazil. \\ 2. Hospital das Clínicas de Ribeirão Preto, Department of Biomechanics, Medicine, and Rehabilitation of the Locomotor Apparatus, Ribeirão Preto, SP, Brazil.
}

\begin{abstract}
Objective: To evaluate the variability of spinopelvic sagittal parameters and the distribution of lordosis in the lumbar spine in a sample of patients. Methods: This is a cross-sectional study considering full-spine radiographs of a patient sample. The patients were classified according to the Roussouly classification and both radiographic spinopelvic alignment parameters and the lordosis measurement of each lumbar spinal segment were considered. The radiographic parameters were correlated with the Roussouly classification type. Results: Ninety patients were included in the study. There was significant correlation between pelvic incidence (PI) and lumbar lordosis $(\mathrm{LL})(\mathrm{R}=0.89$; $p<0.0001)$. The values of PI were significantly higher in Roussouly types 3 and 4 than in types 1 and $2(p<0.001)$, as were the values of LL L1-S1 $(p<0.001)$. Considering the total sample, $67 \%$ of LL L1-S1 was located between L4-S1, but with variations by the Roussouly classification curve types. Conclusion: This study demonstrated a high correlation between the values of PI and LL, as well as the importance of the distal lumbar segment (L4-S1) in the overall value of LL L1-S1, which was even higher in patients with a lower PI value (Roussouly types 1 and 2). Level of evidence II; Retrospective analysis of a prospective database (Cohort); Diagnostic study.
\end{abstract}

Keywords: Spine; Classification; Bone Malalignment; Radiography.

\section{RESUMO}

Objetivo: Avaliar a variabilidade dos parâmetros sagitais espinopélvicos em uma amostra de pacientes, assim como a distribuição de Iordose no segmento lombar da coluna vertebral. Métodos: Trata-se de um estudo transversal, considerando radiografias da coluna total de uma amostra de pacientes. Os pacientes foram avaliados de acordo com a classificação de Roussouly e foram considerados os parâmetros radiográficos do alinhamento sagital espinopélvico, além da medida da lordose de cada segmento da coluna lombar. Os parâmetros radiográficos foram correlacionados com o tipo da classificação de Roussouly. Resultados: Noventa pacientes foram incluídos no estudo. Houve correlação significativa entre a incidência pélvica (IP) e a lordose lombar (LL) L1-S1 ( $R=0,89 ; p<0,0001)$. O valor da IP foi significativamente maior nos tipos 3 e 4 de Roussouly do que nos tipos 1 e $2(p<0,001)$, assim como o valor da LL L1-S1 $(p<0,001)$. Considerando o total da amostra, 67\% da LL L1-S1 estava localizada entre L4-S1, porém com variação conforme o tipo de curva pela classificação de Roussouly. Conclusões: O presente estudo demonstrou grande correlação entre os valores da IP e da LL, assim como a importância do segmento lombar distal (L4-S1) no valor global da LL L1-S1, ainda maior nos pacientes com menor valor de IP (tipos 1 e 2 de Roussouly). Nível de evidência II; Análise retrospectiva de banco de dados prospectivo (coorte); Estudo diagnóstico.

Descritores: Coluna Vertebral; Classificação; Mau Alinhamento Ósseo; Radiografia.

\section{RESUMEN}

Objetivo: Evaluar la variabilidad de los parámetros sagitales espinopélvicos en una muestra de pacientes, así como la distribución de lordosis en el segmento lumbar de la columna vertebral. Métodos: Se trata de un estudio transversal, considerando radiografías de la columna total de una muestra de pacientes. Los pacientes fueron evaluados de acuerdo con la clasificación de Roussouly y fueron considerados los parámetros radiográficos de la alineación sagital espinopélvica, además de la medida de la lordosis de cada segmento de la columna lumbar. Los parámetros radiográficos fueron correlacionados con el tipo de la clasificación de Roussouly. Resultados: Fueron incluidos 90 pacientes en el estudio. Hubo correlación significativa entre la incidencia pélvica (IP) y la lordosis lumbar (LL) L1-S1 ( $R=0,89 ; p<0,0001$ ).). El valor de la IP fue significativamente mayor en los tipos 3 y 4 de Roussouly que en los tipos 1 y 2 ( $p<0,001$ ), así como el valor de la LL L1-S1 ( $p<0,001)$. Considerando el total de la muestra, 67\% de la LL L1-S1 estaba localizada entre L4-S1, aunque con variación conforme al tipo de curva por la clasificación de Roussouly. Conclusiones: El presente estudio demostró gran correlación entre los valores de la IP y de la LL, así como la importancia del segmento lumbar distal (L4-S1) en el valor global de la LL L1-S1, aún mayor en los pacientes con menor valor de IP (tipos 1 y 2 de Roussouly). Nivel de evidencia II; Análisis retrospectivo de banco de datos prospectivo (cohorte), Estudio diagnóstico.

Descriptores: Columna Vertebral; Clasificación; Desviación Ósea; Radiografía. 


\section{INTRODUCTION}

The study of the sagittal balance of the sagittal spine has become popular in recent decades with prolific evidence showing the correlation between the loss of spinopelvic sagittal alignment and the deterioration of function and the quality of life..$^{1-4}$ Thus, numerous radiographic parameters have been described for an understanding of spinopelvic sagittal alignment, as well as for the recognition of loss of alignment. ${ }^{1,2,5,6}$

Among these radiographic parameters, pelvic shape and position parameters stand out, ${ }^{7}$ as well as lumbar lordosis (LL), measured between $\mathrm{L} 1$ and $\mathrm{S} 1$, and the relationship between $\mathrm{LL}$ and pelvic incidence (PI). ${ }^{5}$ However, some authors question the concept of fixed anatomical intervals for different spinal curvatures, including thoracic kyphosis measured between T4 and T12 and lumbar lordosis between T1 and S1. Berthonaud et al., for example, presented the concept of "inflection point" as a functional variable that corresponds to the point of transition between lumbar lordosis and thoracic kyphosis, regardless of the anatomical level where this occurs, and the concept of the variability of the extension of the curvatures of the spine. ${ }^{8}$

Roussouly et al. presented a classification system for normal variants of sagittal alignment of the spine, taking the form and inclination of the pelvis and the distribution of lordosis throughout the lumbar segment into account, considering the "inflection point". ${ }^{9}$ Four types of curves were described ${ }^{9}$ and recently a fifth type was included. ${ }^{10}$ The objective of this study was to evaluate the variability of spinopelvic sagittal alignment parameters in a sample of patients, as well as the distribution of lordotic curvature in the lumbar segment of the spine.

\section{METHODS}

This is a prospective, cross-sectional analysis of a radiographic database of patients treated at an outpatient spine pathology clinic of a single service. The study was approved by the Institutional Review Board of the service responsible for the study (CAAE: 97266618.0.0000.5463), which waived collection of the signed Informed Consent Form as the study considered only data already established in a radiographic database.

Full spinal radiography examinations (panoramic X-rays of the spine) of individuals older than 18 years of age were included, which allowed the evaluation and measurement of the spinopelvic parameters of interest. Examinations of patients with a previous history of neurological or spinal surgery, neurological or neuromuscular disease, trauma, or neoplastic disease of the spine and complaints of hip, knee, foot, or ankle disability that might alter the position of the joints were excluded.

\section{Data collection}

All radiographic examinations were performed at the same service following a standardized technique, with patients standing, comfortable, with the elbow in full flexion and the shoulder in $45^{\circ}$ flexion with the hands relaxed and the fingers resting on the clavicle or the malar bone. ${ }^{11,12}$ The radiographic parameters of interest were measured and analyzed using Surgimap Spine software (Nemaris Inc. New York, USA), validated for the measurement of radiographic spinal parameters. ${ }^{13}$ The lordosis of each segment was measured (L1-L2, L2-L3, L3-L4, L4-L5, and L5-S1), as well as the LL between L1 and S1. (Figure 1) We also considered the parameters PI, pelvic tilt (PT), sacral slope (SS), and the discrepancy between PI and LL (PI-LL). The demographic data and medical records of the patients were also considered. The patients were classified according to the sagittal alignment characteristics using the system proposed by Roussouly et al. ${ }^{9}$

Statistical analysis was performed using $R$ software, version 3.4.9 (R Foundation for Statistical Computing, Vienna, Austria). The data consisted of quantitative variables and the normality of distribution was verified by the Shapiro-Wilk test. Radiographic parameters were compared among the different Roussouly classification types using the ANOVA test. The significance level considered was 5\%.

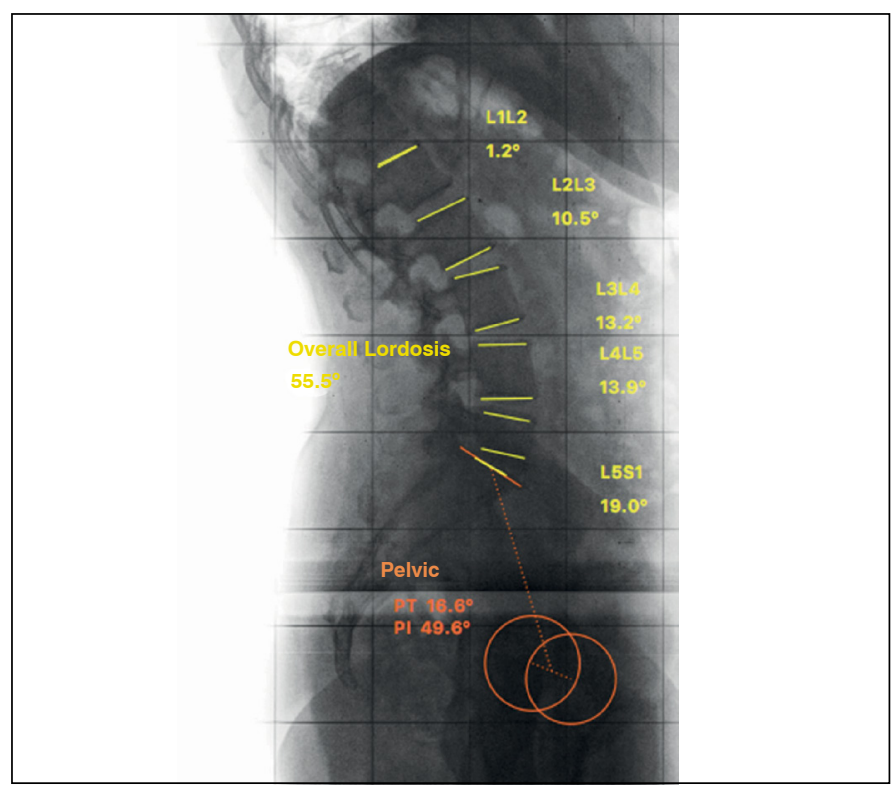

Figure 1. Illustration of the measurement of the radiographic parameters considered in the study.

\section{RESULTS}

Ninety patients met the inclusion criteria and were considered in the study. (Table 1) Of these, 66 patients (73\%) were women and $24(27 \%)$ were men. The mean age of the patients was 56.2 years (standard deviation [SD]: 14.6), ranging from 18 to 95 years of age. Regarding the Roussouly classification, 14 patients (15.6\%) were classified as type 1, $18(20 \%)$ as type 2, $38(42.2 \%)$ as type 3, and $20(22.2 \%)$ as type 4.

\section{Radiographic parameters}

The mean PI value, considering the total sample, was 53.6 SD: 12), ranging from $22^{\circ}$ to $88^{\circ}$. The mean value of $\mathrm{PT}$ was $13.6^{\circ}$ (SD: $7.3^{\circ}$ ) and the mean value of SS was $40^{\circ}\left(\mathrm{SD}: 9.4^{\circ}\right)$. The mean value of $\mathrm{LL}$ between $L 1$ and $S 1$ was $57.8^{\circ}$ (SD: $11.2^{\circ}$ ), ranging from $27^{\circ}$ to $80^{\circ}$. There was a significant correlation between the PI and the LL L1-S1 $(R=0.89, p<0.0001)$. The mean value of the lordosis of the distal lumbar spine segment between L4-S1 was $39^{\circ}$, corresponding to 2/3 $(67.2 \%)$ of the total LL between L1-S1. The mean value of PI-LL, considering the total sample, was $-4.2^{\circ}$ (SD: 5.3 ), ranging from $-10^{\circ}$ to $8^{\circ}$.

\section{Relationship between the radiographic parameters and the Roussouly classification}

Table 2 illustrates the relationship between the radiographic parameters and the Roussouly classification. The PI value was significantly different among the Roussouly classification types $(\mathrm{p}<0.001)$, with a mean $\mathrm{PI}$ value of $40.2^{\circ}\left(\mathrm{SD}: 9.4^{\circ}\right)$ for type $1,46^{\circ}$ (SD: $5.4^{\circ}$ ) for type $2,54.7^{\circ}$ (SD: $6^{\circ}$ ) for type 3 , and $67.7^{\circ}$ (SD: $10.8^{\circ}$ ) for type 4. (Figure 2) The PI was statistically different between types 1 and 3 ( $p<0.001), 1$ and $4(p<0.001), 2$ and $3(p=0.001)$, 2 and $4(p<0.001)$, and 3 and $4(p<0.001)$. (Figure 3$)$ There was no difference in PI between types 1 and $2(p=0.16)$.

The value of the LL was significantly different between the Roussouly classification types ( $p<0.001)$, with a mean $\mathrm{PI}$ value of $47.3^{\circ}$ (SD: $9.5^{\circ}$ ) for type $1,48.1^{\circ}\left(\mathrm{SD}: 7.8^{\circ}\right.$ ) for type $2,59.4^{\circ}$ (SD: $4.9^{\circ}$ ) for type 3 , and $70.8^{\circ}$ (SD: $8.1^{\circ}$ ) for type 4 . (Figure 4) The PI was statistically different between types 1 and 3 ( $p<0.001), 1$ and 4 $(p<0.001), 2$ and $3(p<0.001), 2$ and $4(p<0.001)$, and 3 and $4(p<0.001)$. (Figure 5) There was no difference in the $L L$ between types 1 and 2 ( $p=0.991)$.

Considering the Roussouly type 1 patients, lordosis of the distal segment of the lumbar spine (L4-S1) corresponded to $76.3 \%$ of the LL L1-S1 with the inflection point located at L2-L3. In the Roussouly type 2 patients, the lordosis between L4-S1 corresponded to $62 \%$ of 
Table 1. Demographic data of the sample and distribution by the Roussouly classification.

\begin{tabular}{c|c}
\hline Total sample & 90 patients (100\%) \\
\hline Men & 24 patients (27\%) \\
\hline Women & 66 patients (73\%) \\
\hline \multicolumn{2}{|c}{ Age } \\
\hline Mean (Standard Deviation) & 56.2 years (14.6) \\
\hline Range & $18-95$ years \\
\hline \multicolumn{2}{|c}{ Roussouly classification } \\
\hline Type 1 & 14 patients (15.6\%) \\
\hline Type 2 & 18 patients (20\%) \\
\hline Type 3 & 38 patients (42.2\%) \\
\hline Type 4 & 20 patients (22.2\%)
\end{tabular}

Table 2. Distribution of the PI and the LL according to Roussouly classification curve type.

\begin{tabular}{c|c|c|c|c|c|c|c}
\hline Classification & PI & LL L1-S1 & L1-L2 & L2-L3 & L3-L4 & L4-L5 & L5-S1 \\
\hline \multirow{2}{*}{ Type 1 } & $\begin{array}{c}40.2^{\circ} \\
\left(9.4^{\circ}\right)\end{array}$ & $\begin{array}{c}47.4^{\circ} \\
\left(9.6^{\circ}\right)\end{array}$ & $\begin{array}{c}-2^{\circ} \\
\left(2.3^{\circ}\right)\end{array}$ & $\begin{array}{c}3.9^{\circ} \\
\left(2.7^{\circ}\right)\end{array}$ & $10^{\circ}\left(4^{\circ}\right)$ & $\begin{array}{c}15.9^{\circ} \\
\left(3.2^{\circ}\right)\end{array}$ & $\begin{array}{c}20.5^{\circ} \\
\left(4.9^{\circ}\right)\end{array}$ \\
\hline \multirow{2}{*}{ Type 2 } & $\begin{array}{c}46^{\circ} \\
\left(5.4^{\circ}\right)\end{array}$ & $\begin{array}{c}48.1^{\circ} \\
\left(7.8^{\circ}\right)\end{array}$ & $\begin{array}{c}0.1^{\circ} \\
\left(3.2^{\circ}\right)\end{array}$ & $\begin{array}{c}7.5^{\circ} \\
\left(3.4^{\circ}\right)\end{array}$ & $\begin{array}{c}10.6^{\circ} \\
\left(3.3^{\circ}\right)\end{array}$ & $\begin{array}{c}14.5^{\circ} \\
\left(4.5^{\circ}\right)\end{array}$ & $\begin{array}{c}16.4^{\circ} \\
\left(5.9^{\circ}\right)\end{array}$ \\
\hline \multirow{2}{*}{ Type 3 } & $\begin{array}{c}54.7^{\circ} \\
\left(6^{\circ}\right)\end{array}$ & $\begin{array}{c}59.4^{\circ} \\
\left(4.9^{\circ}\right)\end{array}$ & $\begin{array}{c}0.2^{\circ} \\
\left(3.2^{\circ}\right)\end{array}$ & $7^{\circ}\left(3.5^{\circ}\right)$ & $\begin{array}{c}10.7^{\circ} \\
\left(3.8^{\circ}\right)\end{array}$ & $\begin{array}{c}17.9^{\circ} \\
\left(4^{\circ}\right)\end{array}$ & $\begin{array}{c}24.4^{\circ} \\
(6.4)\end{array}$ \\
\hline \multirow{2}{*}{ Type 4 } & $\begin{array}{c}67.6^{\circ} \\
(10.8)\end{array}$ & $70.8^{\circ}\left(8^{\circ}\right)$ & $1.9^{\circ}\left(3^{\circ}\right)$ & $\begin{array}{c}10.5^{\circ} \\
\left(4^{\circ}\right)\end{array}$ & $\begin{array}{c}14^{\circ} \\
\left(4.1^{\circ}\right)\end{array}$ & $\begin{array}{c}20.6^{\circ} \\
\left(5.4^{\circ}\right)\end{array}$ & $\begin{array}{c}25.3^{\circ} \\
\left(10.1^{\circ}\right)\end{array}$ \\
\hline
\end{tabular}

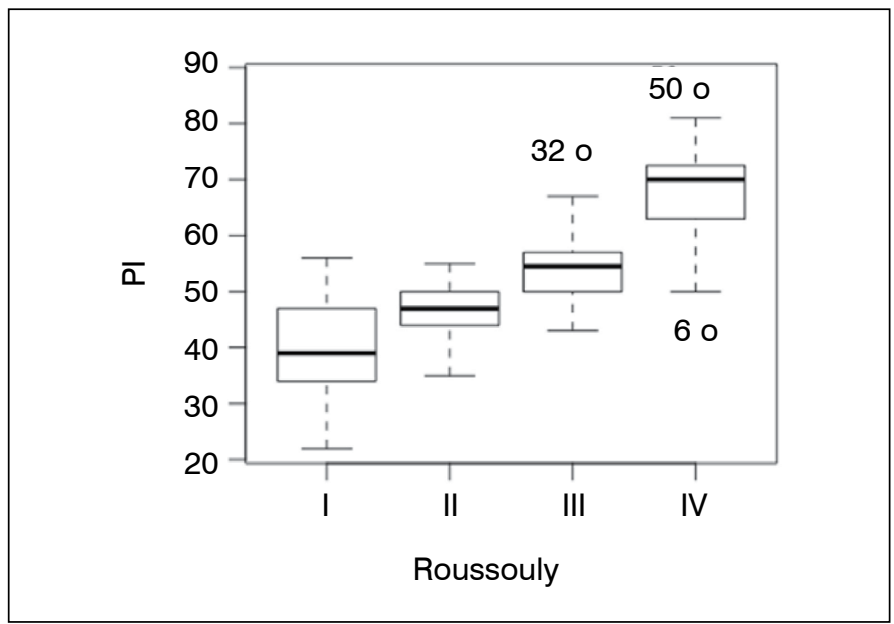

Figure 2. Values of pelvic incidence (PI) according to the Roussouly classification

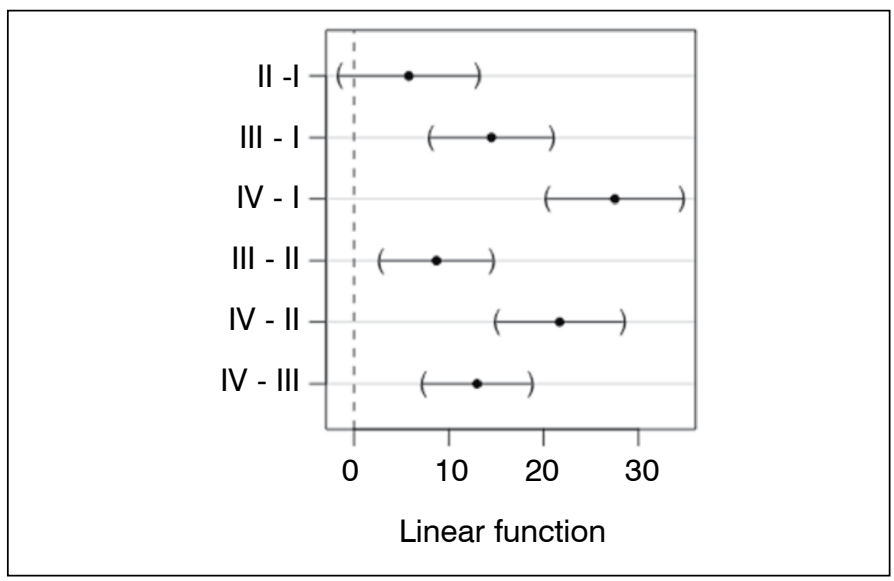

Figure 3. Comparison of the PI values among the Roussouly classification types through the ANOVA test.

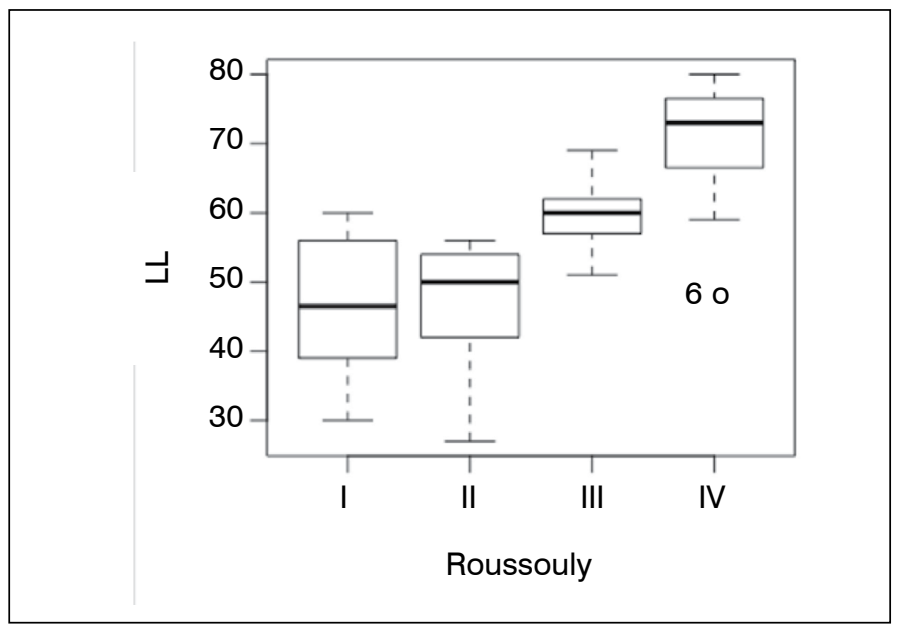

Figure 4. Lumbar lordosis L1-S1 (LL) values according to the Roussouly classification.

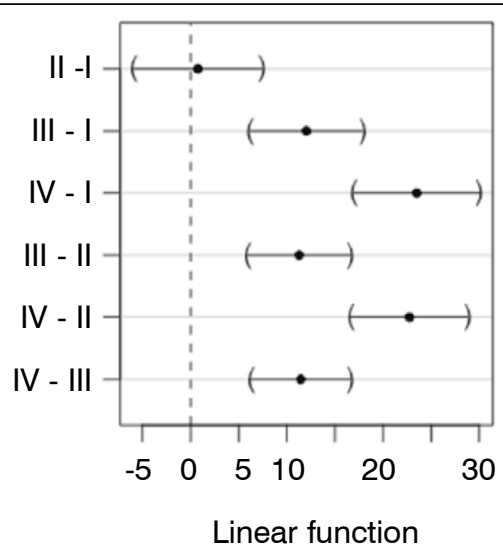

Figure 5. Comparison of the LL values among the Roussouly classification types through the ANOVA test.

the LL L1-S1 with the inflection point located at L1-L2. In the Roussouly type 3 patients, the lordosis between L4-S1 corresponded to $70.8 \%$ with the inflection point located at T12-L1. In the Roussouly type 4 patients, the lordosis between L4-S1 corresponded to $60.9 \%$ with the inflection point located at T12-L1.

\section{DISCUSSION}

It is well established that $L L$ is dependent on the PI value and an increase in the PI value is directly proportional to the absolute value of the LL measured between L1-S1. ${ }^{14}$ However, in addition to the absolute value, a variation in the PI value also influences the behavior of the lumbar curvature, especially the extent of lordosis distribution. This concept was observed by Roussouly and was the basis for the classification system for the normal variants of sagittal spinal alignment presented. ${ }^{9}$ This study evaluated a sample of patients for spinopelvic sagittal alignment and classification according to the system proposed by Roussouly.

Laouissat et al. ${ }^{10}$ investigated the accuracy of the Roussouly classification, in a study with 296 individuals. Comparing their results with the results of our study, type 1 was the least frequent in both (12\% vs. $15.6 \%$, respectively), while type 3 was the most common in both (46\% vs. $42.4 \%$ ). In the article cited, type 2 accounted for $22 \%$ while in our study type 2 accounted for $20 \%$. Type 4 made up $20 \%$ of the population in the Laouissat et al. study and $22.2 \%$ in our study.

Regarding the relationship between the radiographic parameters and the Roussouly classification, in this study we observed that the $\mathrm{PI}$ value was higher for types 3 and 4 than for types 1 and 2, with the 
Roussouly type 4 value being higher than that of type 3 . This result agrees with what was published in the original article by Roussouly et al., ${ }^{9}$ as well as with the Laouissat et al. article. ${ }^{10}$ Likewise, the LL L5-S1 value was higher in types 3 and 4 , being higher in type 4 than in type 3 , as compared to types 1 and 2, just as observed in the cited articles. ${ }^{9,10}$

The literature has shown that 2/3 of the total LL L1-S1 is located in the distal segment of the lumbar spine (L4-S1). ${ }^{9,15}$ Data from the present study showed that, in the total sample, segment L4-S1 was responsible for $67.2 \%$ of the LL L1-S1 value. Considering the different Roussouly classification types, the distribution of lordosis varied by lumbar segment: Type 1, with patients with low PI (mean $40^{\circ}$ ) and short lordosis, usually comprising three vertebrae, $76 \%$ of the LL L1-S1 being located between L4-S1; Type 2, also with low $\mathrm{PI}\left(46^{\circ}\right)$ and a less pronounced lumbar curve (LL L1-S1 mean $48^{\circ}$ ), $62 \%$ of the LL L1-S1 located between L4-S1; Type 3, with a mean PI of $54^{\circ}$, with an increase in the number of vertebrae comprising the lordosis and $70 \%$ of the LL L1-S1 located between L4-S1; and Type 4 , with a higher $\mathrm{PI}$ (mean $67^{\circ}$ ), a more pronounced and extensive LL (mean $70^{\circ}$ ), with $60 \%$ of the LL L1-S1 located between L4-S1.

A recent study evaluated spinopelvic sagittal alignment considering a sample of 268 individuals. ${ }^{16}$ It was also observed that $67 \%$ of the lumbar lordosis was located between $\mathrm{L} 4$ and $\mathrm{S} 1$, similar to that observed in our study and the other published articles. Moreover, the correlation between LL and PI was analyzed and an arithmetic expression was obtained from the linear regression model in which $\mathrm{LL} \mathrm{L1-S1}=0.54 x \mathrm{PI}+27.6(\mathrm{R}=0.56)$. Thus, they demonstrated that in patients with lower $\mathrm{PI}\left(\mathrm{PI}<50^{\circ}\right)$ the value of $\mathrm{LL}$ is expected to be higher than the $\mathrm{PI}$ value, while in patients with higher $\mathrm{Pl}$ it is expected that the LL value will be lower than that of the PI, respecting the concept presented in the article by Schwab et al. that $\mathrm{LL}=\mathrm{PI} \pm$ $9^{\circ} .{ }^{14}$ In our study, we also observed a strong correlation between $\mathrm{PI}$ and $\mathrm{LL}$, and by the linear regression model the value of LL L1-S1 = $0.83 x P I+13$, with $R=0.89$ and $R^{2}=0.80(p<0.001)$.

\section{CONCLUSIONS}

This study presented an analysis of spinopelvic sagittal alignment in a sample of Brazilian patients and calculated the frequency distribution rate according to the Roussouly classification. The high correlation between PI and LL values was confirmed. We observed the important influence of the distal lumbar segment (L4-S1) in the overall values of LL L1-S1, even more significant in patients with lower PI (Roussouly types 1 and 2).

All authors declare no potential conflict of interest related to this article.

CONTRIBUTION OF THE AUTHORS: Each author made significant individual contributions to this manuscript. Study concept and design: RRP. Data acquisition and IRB approval: LEMP. Data collection: LEMP. Data analysis and interpretation: RRP. Development of the article: RRP. Critical review of the article: CFPSH. Review of the final version for submission: RRP, LEMP, CEASO, and CFPSH.

\section{REFERENCES}

1. Glassman SD, Bridwell K, Dimar JR, Horton W, Berven S, Schwab F. The impact of positive sagittal balance in adult spinal deformity. Spine (Phila Pa 1976). 2005;30(18):2024-9.

2. Lafage V, Schwab F, Patel A, Hawkinson N, Farcy JP. Pelvic tilt and truncal inclination: two key radiographic parameters in the setting of adults with spinal deformity. Spine (Phila Pa 1976). 2009;34(17):E599-606.

3. Bess S, Line B, Fu KM, McCarthy I, Lafage V, Schwab F, et al. The health impact of symptomatic Adult Spinal Deformity: Comparison of deformity types to United States population norms and chronic diseases. Spine (Phila Pa 1976). 2016;41(3):224-33.

4. Pellisé $F$, Vila-Casademunt $A$, Ferrer $M$, Domingo-Sàbat $M$, Bagó J, Pérez-Grueso FJ et al. Impact on health related quality of life of adult spinal deformity (ASD) compared with other chronic conditions. Eur Spine J. 2015;24(1):3-11.

5. Schwab FJ, Blondel B, Bess S, Hostin R, Shaffrey Cl, Smith JS, et al. Radiographical spinopelvic parameters and disability in the setting of adult spinal deformity: a prospective multicenter analysis. Spine (Phila Pa 1976). 2013;38(13):E803-12.

6. Pratali RR, Hennemann SA, Amaral R, Silva LECT, Carvalho MOP, Daher MT, et al. Standardized terminology of adult spine deformity for brazilian portuguese. Coluna/ Columna. 2015;14(4):281-5.

7. Legaye J, Duval-Beaupère G, Hecquet J, Marty C. Pelvic incidence: a fundamental pelvic parameter for three-dimensional regulation of spinal sagittal curves. Eur Spine J. 1998:7(2):99-103.

8. Berthonnaud E, Dimnet J, Roussouly P, Labelle H. Analysis of the sagittal balance of the spine and pelvis using shape and orientation parameters. J Spinal Disord Tech. 2005;18(1):40-7
9. Roussouly P, Gollogly S, Berthonnaud E, Dimnet J. Classification of the normal variation in the sagittal alignment of the human lumbar spine and pelvis in the standing position. Spine (Phila Pa 1976). 2005;30(3):346-53

10. Laouissat F, Sebaaly A, Gehrchen M, Roussouly P. Classification of normal sagittal spine alignment: refounding the Roussouly classification. Eur Spine J. 2018;27(8):2002-11

11. Glassman SD, Bridwell K, Dimar JR, Horton W, Berven S, Schwab F. The impact of positive sagittal balance in adult spinal deformity. Spine (Phila Pa 1976). 2005;30(18):2024-9.

12. Pratali RR, Nasreddine MA, Diebo B, Oliveira CEAS, Lafage V. Normal values for sagittal spinal alignment: a study of Brazilian subjects. Clinics (Sao Paulo). 2018;73:e647.

13. Lafage R, Ferrero E, Henry JK, Challier V, Diebo B, Liabaud B, et al. Validation of a new computer-assisted tool to measure spino-pelvic parameters. Spine $\mathrm{J}$. 2015;15(12):2493-502

14. Schwab F, Lafage V, Patel A, Farcy JP. Sagittal plane considerations and pelvis in the adult patient. Spine (Phila Pa 1976). 2009;34(17):1828-33.

15. Janik TJ, Harrison DD, Cailliet R, Troyanovich SJ, Harrison DE. Can the sagittal lumbar curvature be closely approximated by an ellipse? J Orthop Res. 1998;16(6):766-70.

16. Le Huec JC, Hasegawa K. Normative values for the spine shape parameters using 3D standing analysis from a database of 268 asymptomatic Caucasian and Japanese subjects. Eur Spine J. 2016;25(11):3630-7. 